\title{
OCCURRENCE OF LINDERNIA DUBIA IN THE IPOLY VALLEY (HUNGARY AND SLOVAKIA)
}

\author{
András Schmotzer \\ Bükk National Park Directorate, H-3304 Eger, Sánc u. 6, Hungary; schmotzera@bnpi.hu
}

Schmotzer, A. (2015): Occurrence of Lindernia dubia in the Ipoly valley (Hungary and Slovakia). - Studia bot. hung. 46(1): 77-89.

\begin{abstract}
A survey for invasive alien species was carried out along the Ipoly River (Danube catchment area) at the border between Hungary and Slovakia in 2010 and 2011. Lindernia dubia was found in three locations on both sides of the river. The paper gives the first record of the species in the Ipoly (Ipel') Catchment Area (Hungary and Slovakia), previously, the species has not been reported from the Matricum flora district of Hungary. This paper describes the newly discovered localities (status of phenology, accompanied species, ecological and hydrological conditions, etc.). It also explains the spread and possible regional origin of the species. The recent CEU-based distribution map is also presented.
\end{abstract}

Key words: alien plant, flora of Central Europe, Lindernia dubia, Ipoly Catchment, Hungary, Slovakia

\section{INTRODUCTION}

Floodplains are one of the most invaded habitats, mostly due to their "landscape sink" position. The inflowing debris, flooding, continuous propagules and disturbances have a significant role in the spreading of invasive alien plant species (ZEDLER and KERCHER 2004). The most successful alien species invade new habitats along watercourses (PYŠEK and PraCh 1993). BURKART (2001) analysed the plant distribution pattern following river corridors and found that occurrences of some non-native species (such as Lindernia dubia, Xanthium spp.) were also restricted to river corridors in Central Europe.

Traditionally the genus Lindernia was regarded as a member of the Scrophulariaceae family. The recently outlined Linderniaceae are a monophyletic group that has emerged in the course of the disintegration of the Scrophulariaceae in the past years (RAHMANZADEH et al. 2005, FISCHER et al. 2013). Lindernia dubia [syn. Capraria gratioloides L., Gratiola anagallidea Michx., G. dubia L., Ilysanthes anagallidea (Michx.) Raf., I. dubia (L.) Barnhart, I. gratioloides Benth., Lindernia anagallidea (Michx.) Pennell, L. pyxidaria Pursh var. major Pursh.] were described in the monograph on the New World's Scrophulariaceae by Pennel (1935). Recently, four varieties have been distinguished within its na- 
tive distribution range: var. rhizomatosa, var. mexicana, var. dubia and var. anagallidea (LEwIs 2001). The latter two were mentioned in the adventive range of the species. Hybridisation and a genetic relationship between $L$. dubia and $L$. procumbens has been reported so far only from Japan (Yoshino et al. 2011).

In its native range, Lindernia dubia occurs on wet ditches, wet meadows, at the border of ponds and lakes and along streams in Canada (Ontario, Quebec, Nova Scotia and Newfoundland) and from the western United States to Argentina. A distributional map of the New World occurrences was prepared by LewIS (2001). The species was introduced to Asia and Europe (WEBB and PHILCox 1972), thus it was overlooked and sometimes wrongly identified as L. procumbens (e.g. in South India, see Prasad and Sunojkuma 2014). The species was introduced to Europe by commercial vessels in the 19th century, the first documented record being from France (LlYOD 1868, FourNIER 1940). The eastward spread of the species in the Old World is well-documented. The Central European occurrences, especially the first reports in the different countries, are presented by ŠUMBEROVÁ et al. (2012). Unfortunately, this paper omits the documentation concerning the Hungarian distribution of the species (MOLNÁR et al. 2000). This latter provides detailed identification features (with comparison of the native $L$. procumbens), phenological and coenotic results and presents the actual UTM grid-map of the species. In Hungary the weighted occurrences are found in South Transdanubia (especially on the Dráva Plain and Somogy County). Despite the fact that this species is non-native, CsIKY and OlÁH (2006) added Lindernia dubia to the local Red List of the Dráva Plain. The northernmost occurrence of the species in Hungary, at Ács municipality was published recently (RIEZING 2012).

In most of the countries the species is regarded as a casual alien or introduced species (e.g. in Hungary see BALOGH et al. 2004). Negative effects on natural habitats are not frequently reported, except in some Mediterranean and Far East countries (usually as a harmful weed of rice paddy fields, see e.g. Italy Molnár et al. 2000, and Japan - Yoshino et al. 2006).

This paper aims (1) to characterize in detail the newly discovered localities, and (2) to hypothesize the origin and potential spread of the species in the Ipoly valley region.

\section{MATERIAL AND METHODS}

\section{The study species}

Lindernia dubia is a summer annual, about $2-18 \mathrm{~cm}$ tall that branches occasionally. The stems are light green to reddish green, 4 -angled, and hairless. The opposite leaves are oval-ovate in shape, light green to reddish green, hairless, and 
smooth along the margins or obscurely dentate. On the upper surface of each leaf 3-5 pale veins are observable, while the base of each leaf is sessile or has a short petiole. Individual flowers are produced from the axils of the upper leaves (one flower per axil). Each flower consists of a tubular calyx with 5 linear teeth and a tubular corolla that curves slightly downward. The corolla is white, pale violet, or a combination of these two colours. The upper lip of the corolla has 2 small lobes that function as a protective hood, while the lower lip of the corolla has 3 lobes that are rounded and spreading. Inside the corolla, there are 2 fertile stamens, 2 sterile stamens, and a single style. The slender pedicel is usually shorter than the leaf underneath the flower. Each flower is replaced by a narrowly ovoid or spindle-shaped seed capsule containing several small seeds. Mature seed capsules are about as long as the teeth of the calyx or slightly longer (GLEAsON and CRONQUist 1991). There are significant differences between Lindernia dubia and L. procumbens in several characteristics (e.g. length of leaves, length of pedicels, ratio of pedicels / leaf length) (MolNár et al. 2000).

\section{The study area}

The newly discovered sites are located along the middle section of the river Ipoly (in Slovakian language: Ipel', in German: Eipel). The extent of the Ipoly catchment area is $5.108 \mathrm{~km}^{2}\left(1.424 \mathrm{~km}^{2}\right.$ belongs to Hungary). The length of the river (after the regulations) is $232.5 \mathrm{~km}$, of which a $143 \mathrm{~km}$ section is a borderline between Hungary and Slovakia. The highest point (in spring in the Veporské vrchy Mts.) in the catchment area is above $1000 \mathrm{~m}$ a.s.l., while the confluence with the Danube River at Szob municipality is barely above $100 \mathrm{~m}$ a.s.l. The flat basins along the river are surrounded by hilly areas such as the Litke-Etes Hills in Hungary and Ipel'ská pahorkatina and Krupinská planina in Slovakia. The Ipoly formed a relatively broad natural floodplain in the middle part of the flow, which is characterised by lowland habitats (Cnidion dubii meadows, Nanocyperion and Bidention communities, remnants of floodplain forests) and species, such as Allium angulosum L., Clematis integrifolia L., Galium boreale L., Pseudolysimachion longifolium (L.) Opiz, etc. (KovÁcs and MÁt É 1967, Hrivná K et al. 1997, 2001). Both sides of the Ipoly River are part of the Natura 2000 network as Sites of Community Interest and / or Special Protection Areas (for the protection of bird species).

The water regime of the Ipoly is very extreme. The annual run-off volume fluctuates at a rate of more than $1: 7$ per year. The ratio of occurrence of the minimum and maximum water yields within one year can vary from $1: 200$ to 1 : 1000 , over a span of several years. These values show even greater extremes at the tributaries (KovÁCS and KATONÁNÉ-KOZÁK 2011). 
The area belongs to the Pannonicum flora from the phytogeographical point of view and is within the Matricum floristic district. According to Futák's phytogeographical map this area is an integral part of the Ipel'sko-rimavská brázda region in Slovakia (FUTÁK 1980) and the Neogradense unit in Hungary (Soó 1973).

The CEU grid numbers added follow the codes of the Central European Flora-mapping project (NIKLFELD 1971, KIRÁLY 2003). Nomenclature of flowering plants is according to KIRÁLY (2009). Geo-coordinates of the localities were determined using a MIO Digiwalker P360 GPS device in Hungarian DATUM projection. The coordinates were converted to the WGS-84 system by the online application of Psoft Informatikai Ltd. (www.psoft.hu). Online historical maps of the Habsburg Empire and cadastral maps were used to study former land-use of the study area (http://mapire.eu/en/).

\section{RESULTS AND DISCUSSION}

An invasive alien species survey was carried out along the Ipoly River (Danube catchment area) at the border between Hungary and Slovakia in 2010 and 2011. Within the framework of this mapping localities of Lindernia dubia (L.) Pennell were observed. The species is not included in Slovak floras and alien lists (ZaHRAdníková and OŤaHEL'OVÁ 1997, MARHOLD and Hindák 1998, MEDVECKÁ et al. 2012); however, has just been reported from Richnavské jazerá Lake (Štiavnické Bane; Central Slovakia) (KochJARová et al. 2015). It has not been mentioned in the flora district of Matricum (Hungary), where all localities belong (KIRÁly 2009).

Lindernia dubia is a rare adventive species in Hungary. After noticing its occurrence in Hungary, MOLNÁR et al. (2000) gave detailed information on its distribution. Recently published data are quite scarce, so the actual distribution map of the species is refined by the Database of the Hungarian Flora Mapping Programme (Fig. 1).

The confirmed locations of Lindernia dubia in the Ipoly Catchment are shown in Figure 2. Recent localities of Lindernia dubia in the middle section of the Ipoly valley are listed in Appendix 1.

The three observed localities have some common features with minor differences. All habitats depend on pioneer muddy surfaces, where temporary Nanocyperion stands could develop. Lindernia dubia was accompanied by other Nanocyperion species in two open (non-woody) localities (Loc-1 and Loc-3) (see Appendix 1). The Loc-2 site is quite peculiar due to its forest canopy cover. The number of individuals is very low here ( 1 and 2 individuals in the two subpopulations, respectively), which might reflect an early phase of introduction.

Two localities (Loc-1 and 2) are situated in the active floodplain; very close to the riverbed (distances from the riverbank are up to 10 metres). Due to the 
active hydrological processes the riverbed rapidly changes course, the streamline - which is the designated state border - has already moved. Loc-3 is situated in the historical floodplain, approx. $70 \mathrm{~m}$ distance from the riverbank. At this site the riverbed was canalised after World War I and was drastically modified in the 1980s. The local name of the locality ("Konopisko" in Slovakian and "Kenderföld" in Hungarian) refers to a place where formerly the cultivated hemp (Cannabis sativa L.) was soaked for weeks in pond water to eliminate soft tissues. After the abandonment of this cultivation activity these human-made depressions could serve as a basis for the development of temporary pools covered by semi-natural mudflat or aquatic vegetation. In many cases these artificial ponds are considered as fossil riverbeds too (DEMETER et al. 2005).

The distance between the two farthest localities (Loc-1 and Loc-3) is 7 kilometres, which means 9.6 river-kilometres (RKM) along the water body. Two riparian localities (Loc-1 and 2) have an apparent surface hydrology connection via the Ipoly River.

The occurrence of the species in the Ipoly catchment area is rather unexpected. The nearest known Hungarian populations of the species are more than 200 kilometres away. The species was also observed in Central Europe in riparian and mudflat habitats. The origins of introduction in the Ipoly valley and possible vectors are not known. The ecology of Lindernia dubia is studied by ŠUMBEROVÁ et al. (2012), so some hypotheses can be formulated.

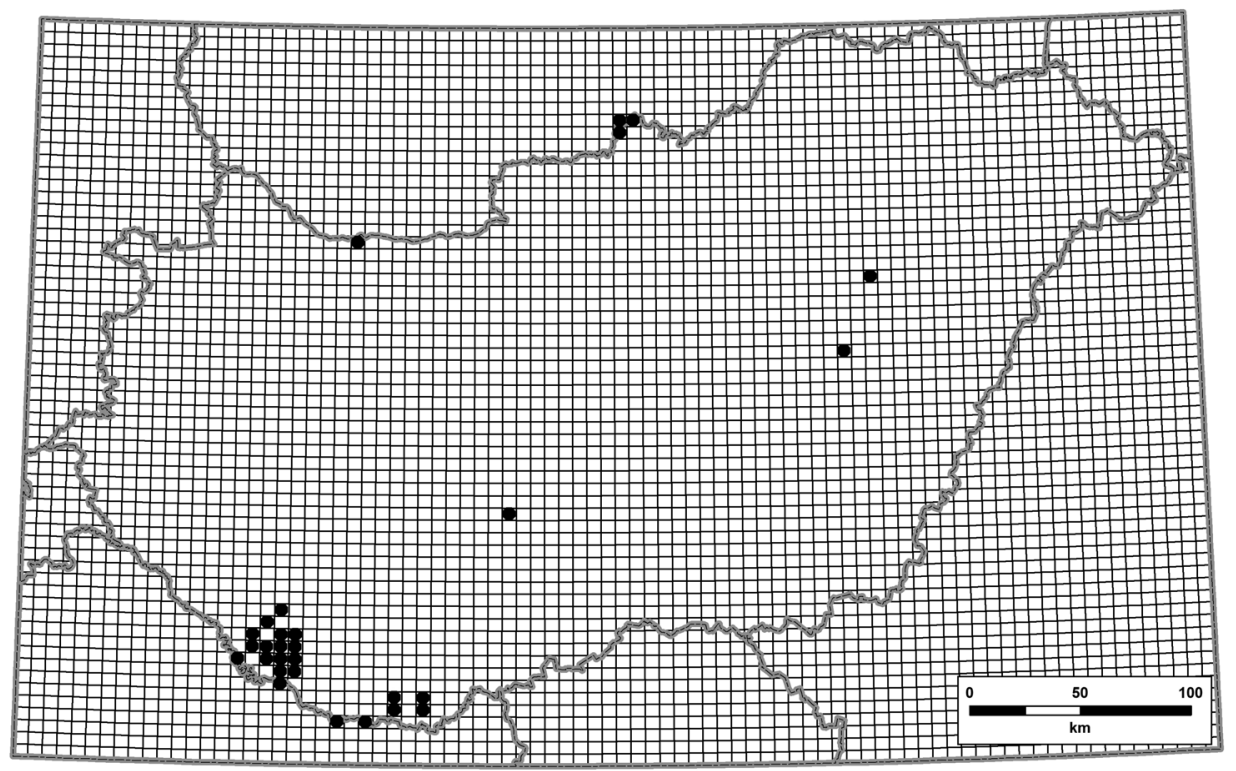

Fig. 1. Recent occurrence of Lindernia dubia in Hungary and Slovakia 
Probably the main vector is dispersal via flowing water, but this is not sufficient for locating the origin of the population. In most cases Lindernia dubia prefers shallow standing water habitats with drastically changing water-levels, such as in fish ponds and fish nurseries. The conditions of some fish ponds in the upper section of the Ipoly River and its tributaries are quite suitable for this mudflat species, such as the Zeleniansky rybník fish pond and the Uhorské Rybníky rybník fish pond at Poltár (Csaba Balázs pers. comm.). The cultivation practice with a periodically drained stage of the water body is suitable for serving a source population of the Nanocyperion species. There is a free flow of goods in the European Union (including fish fry) and although a direct link was not proved, one of the main carp breeding centres is located in the Czech Republic (e.g. Třeboň region in South Bohemia), where Lindernia dubia is rather frequent and its invasion is well documented (KURKA 1990, ŠUMBEROVÁ et al. 2012).

Another possible way of introduction is zoochory. Fish pond wetland habitats are commonly visited by wading birds that gather seeds on their mudencrusted feathers and legs, and can transport propagules to great distances in

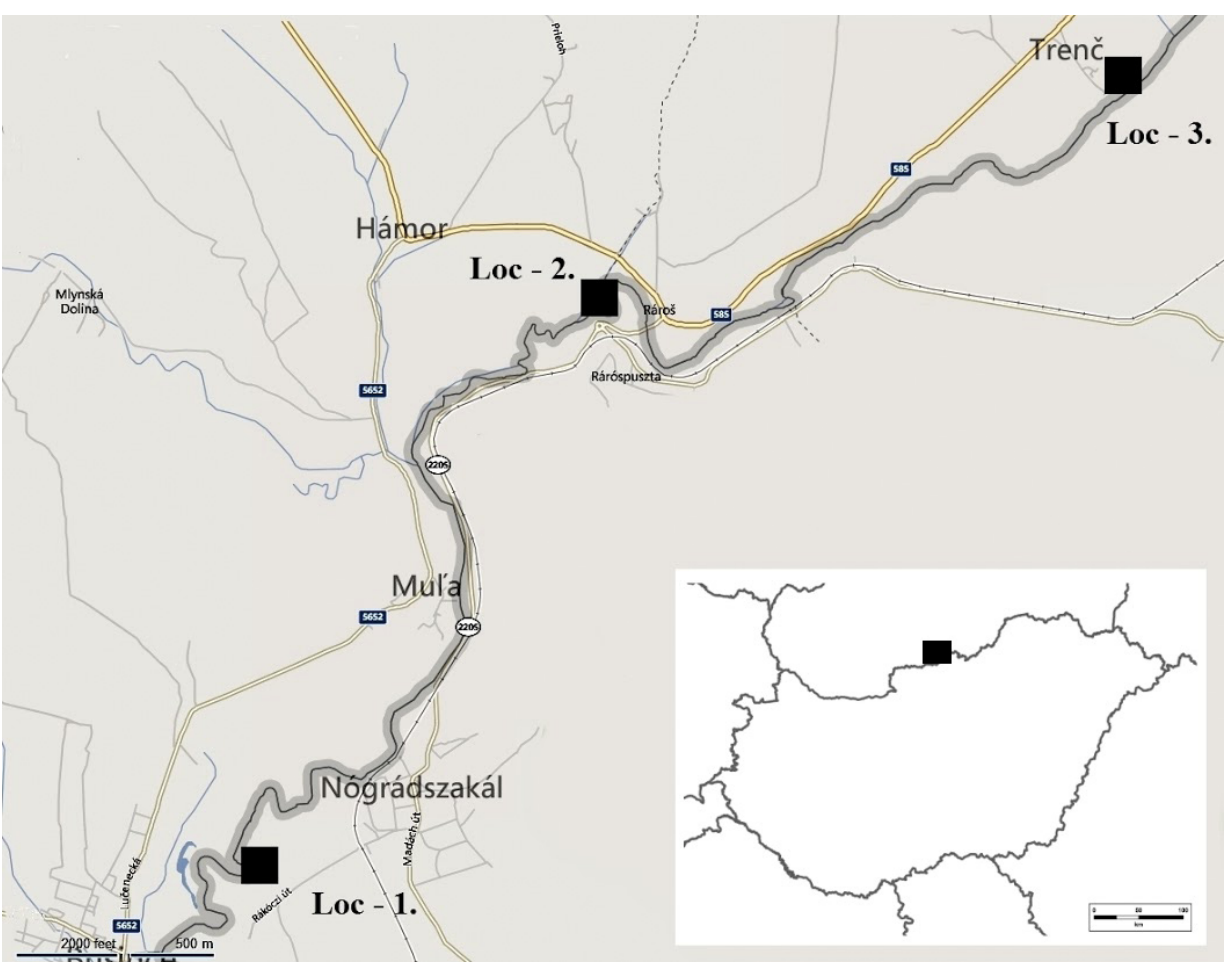

Fig. 2. The localities of Lindernia dubia in the middle section of the Ipoly valley between Trenč and Nógrádszakál 
this manner (FENNER 1985). Nowadays, endozoochorous propagule dispersal is considered to be a lot more important than epizoochory (BROCHET et al. 2009, Vivian-SMith and STILES 1994). The spread of Lindernia dubia could be also a typical example of waterfowl diaspora transport as KIRÁLY and ELIÁš (2011) disputed in the case of Elatine hungarica Moesz distribution in SW Slovakia.

The appearance of Lindernia dubia in the years 2010 and 2011 could be expected, as a result of high flood events. The year 2010 was an extremely wet year, the measured annual precipitation being $1077.6 \mathrm{~mm}$ in the catchments of the Garam (Hron), Vág (Váh) and Ipoly rivers (Kovács and KaTONÁNÉ-KozÁK 2011).

The native Lindernia procumbens has also been found recently in the middle section of the Ipoly valley, but not in the same locations with $L$. dubia (Lučenec - Koštál and Vojteková in Eliáš 2013a, Vel'ká Ves nad Ipl'om - Eliáš 2013b, and Szécsény - unpublished data of present author, K. Harmos and B. Pintér). This species has historical data from the Ipoly catchment presented by HENDRYCH (1968) from Rapovce village, but it has not been known on the Hungarian side of the study area until now.

In my opinion, Lindernia dubia has already reached the phase of "naturalization" in the Ipoly valley, according to the definition used by RICHARDSON $e t$ al. (2000). Concluding from the ecological conditions of the occupied habitat, further spreading of the species in the Ipoly catchment is expected in the future. Further studies are needed in order to (1) find the source of the regional population (e.g. investigation of the fish ponds and nurseries). (2) evaluate the interaction between the adventive Lindernia dubia and the native and threatened L. procumbens.

Acknowledgements - The author would like to thank Pavol Eliáš jun., Attila Molnár V., Patrik Mráz and Csaba Balázs for providing valuable information and relevant pieces of literature for the study. Attila V. Molnár confirmed the correctness of the identification based on the photographs. Albert Vermes kindly improved the English of the text. The fieldwork was partly supported by grant Nr. HUSK/0801/2.2.1/0066 in the framework of the Hungary-Slovakia Cross-border Cooperation Programme 2007-2013 (Bükk National Park Directorate) and grant Nr. 03-2011 of NatuRegio floodplains (NNA Alfred Toepfer Academy). The actual grid map distribution of $L$. dubia data was served by the Database of the Hungarian Flora Mapping Programme (University of West Hungary, Faculty of Forestry, Department of Botany and Nature Conservation, Sopron, Hungary, 2015).

Összefoglaló: A Középső-Ipoly-völgyben, az Ipoly folyó két oldalán 2010-2011-ben az inváziós növényfajok felmérése közben a Lindernia dubia három lelőhelyen került elő Nógrádszakál és Trenč (Tőrincs) települések határában. Ennek az Európa több országában előforduló adventív fajnak az öshazája Észak- és Dél-Amerika. Mivel a közel rokon, Európában honos L. procumbens veszélyeztetett ritkaságnak számít, a $L$. dubia előfordulásai mindenképp figyelmet érdemelnek a két faj átfedő élőhelypreferenciája miatt is (Nanocyperion társulások). 
A fajt csak napjainkban közölték Szlovákiából (Selmecbánya mellől, 2014) és az ismert hazai előfordulások is a Matricum flóravidéken kívül esnek. A dolgozat közli a faj recens hazai és szlovákiai elterjedési térképét is. A tanulmány részletesen ismerteti a felmért termőhelyeket (ökológiai és hidrológiai viszonyok, társuló fajok, Ipolytól való távolság, stb.), melyek számos hasonlóság mellett, eltérő vonásokat is mutatnak. A lelőhelyek között a távolság mintegy $7 \mathrm{~km}$ légvonalban, mely 9,6 folyamkilométernek feleltethető meg. A lelőhelyek távolsága igen közeli a folyóhoz (0-70 m között). A két hazai lelőhely (Nógrádszakál és Ráróspuszta) a hullámtéren fekszik, előbbi lelőhelyén a mederben kisvízkor kialakuló iszapfelszínen, míg utóbbi helyen laza záródású füzliget (Salicetum albae) nyers iszaptalaján észleltem a fajt. A szlovákiai lelőhely Tőrincsnél mentett oldalon található, egykori medermaradványban kialakult belvizes szántóterületen fordul elő több iszapnövényzetre jellemző karakterfaj társaságában. A térképi névanyag és a katonai felmérési térképek tanulsága szerint a mélyedést egykor kenderáztatónak is használták.

A faj váratlan, regionális megjelenésének pontos ideje és oka nem ismert. Az a tény, hogy 2010-ben és 2011-ben az Ipoly mellett (közvetlenül a mederben illetve mellette) két, kis egyedszámú populációja megjelent, a vízzel való terjedést feltételezi (hydrochoria). Ezt alátámasztja az Ipoly vízgyüjtőjén 2010-ben mért rekordmennyiségü csapadék és az ebből következő árvízi események is. Mivel a faj Közép-Európa más országaiban (például Csehországban) kifejezetten kötődik halastavi élőhelyekhez (periodikusan leeresztett halastavak és ivadéknevelő medencék), így az Ipoly felsőbb szakaszán előforduló halastavak potenciális eredetként jelentkezhetnek, így ennek vizsgálatára a szlovákiai halastavak felmérése mindenképp indokolt a jövőben.

\section{REFERENCES}

BAlogh, L., Dancza, I. and Király, G. (2004): A magyarországi neofitonok időszerü jegyzéke, és besorolásuk inváziós szempontból. [Actual list of neophytes in Hungary and their classification according to their success]. - In: MiHÁLY, B. and BotTA-Dukát, Z. (eds): Biológiai inváziók Magyarországon: Özönnövények I. [Biological invasions in Hungary: invasive plants I.]. KvVM Természetvédelmi Hivatalának Tanulmánykötetei 9: 61-92.

Brochet, A. L., Guillemain, M., Fritz, H., Gauthier-Clerc, M. and Green, A. J. (2009): Plant dispersal by teal (Anas crecca) in the Camargue: duck guts are more important than their feet. - Freshwater Biol. 55: 1262-1273. http://dx.doi.org/10.1111/j.1365-2427.2009.02350.x

BURKarT, M. (2001): River corridor plants (Stromtalpflanzen) in Central European lowland: a review of a poorly understood plant distribution pattern. - Global Ecol. Biogeogr. 10: 449-468. http://dx.doi.org/10.1046/j.1466-822x.2001.00270.x

Csı KY, J. and OlÁH, E. (2006): A Drávamenti-síkság Nanocyperion jellegü fajainak vörös listája. [The red list of Nanocyperion like species in Dráva Plain (South Hungary]. - Natura Somogyiensis 9: 5-26.

Demeter, L., PÁsztohy, Z., Csergö, A.-M. and Cărăuş, I. (2005): Terrace ponds in the Ciuc Basin: a preliminary characterization. - Stud. Cercet. Biol., Univ. Bacău 10: 19-23.

Elıášs, P. jun. (ed.) (2013a): Zaujímavejšie floristické nálezy. - Bull. Slov. Bot. Spoločn. 35(1): 96-107.

Elı śš, P. jun. (ed.) (2013b): Zaujímavejšie floristické nálezy. - Bull. Slov. Bot. Spoločn. 35(2): 214-224.

FENNER, M. (1985): Seed ecology. - Chapman and Hall, London, 151 pp.

Fischer, E., SCHÄFERHOFF, B. and MÜlLER, K. (2013): The phylogeny of Linderniaceae - the new genus Linderniella, and new combinations within Bonnaya, Craterostigma, Lindernia, Micranthemum, Torenia and Vandellia. - Willdenowia 43: 209-238. http://dx.doi.org/10.3372/wi.43.43201

FutÁk, J. (1980): Fytogeografické členenie. - In: MAzÚR, E. (ed.), Atlas Slovenskej socialistickej republiky. Slovenská akadémia vied, Bratislava, p. 88, mapa VII/14. 
Gleason, H. A. and Croneuist, A. (1991): Manual of vascular plants of Northeastern United States and Adjacent Canada. 2nd ed. - The New York Botanical Garden. Bronx, NY. pp. 910.

HENDRYCH R. (1968): Ad floram regionis Filakoviensis in Slovacia addenda critica. - Acta Univ. Carol., Biol. 1967: 109-183.

Hrivnák, R., CVaChová, A, OŤahelová, H. and Valachovič, M. (1997): Príspevok k poznaniu flóry povodia Ipl'a a Slanej. [Contribution to the knowledge of flora of the catchment areas of Ipel' and Slaná]. - In: Urban, P. and Hrivnák, R. (eds): Poiplie. SAŽP, B. Bystrica, pp. 11-25.

Hrivnák, R., OŤahelová, H., VAlachovič, M., Cvachová, A. and BALÁzs, P. (2001): Aquatic and marsh plant communities of an inundation area of the Ipel' river (rkm 96-119). - Kitaibelia 6 (2): 267-279.

KIRÁLY, G. (2003): A magyarországi flóratérképezés módszertani alapjai. Útmutató és magyarázat a hálótérképezési adatlapok használatához. [Methodik und Ziele der Florenkartierung in Ungarn]. - Flora Pannonica 1(1): 3-20.

Király, G. (2009) (ed.): Új Magyar Füvészkönyv. Magyarország hajtásos növényei. Határozókulcsok. [New Hungarian herbal. The vascular plants of Hungary. Identification key]. Aggteleki Nemzeti Park Igazgatóság, Jósvafö, 616 pp.

Király, G. and Eliáš, P. jun. (2011): Elatinka mad'arská (Elatine hungarica) na Podunajskej nížine. [Elatine hungarica in the Danube Lowland]. - Bull. Slov. Bot. Spoločn. 33(1): 33-38.

Kochjarová, J., HrivnáK, R. and LETZ, D. R. (2015): Flóra a vegetácia na obnaženom dne vypustených vodných nádrží v okolí Zvolena a Banskej Štiavnice. [Flora and vegetation on the bottom of emptied water ponds near the towns of Zvolen and Banská Štiavnica]. - Bull. Slov. Bot. Spoločn. 37(1): 87-102.

KovÁcs, M. and MÁTHÉ, I. (1967): Die Vegetation des Inundationsgebietes der Ipoly. [The vegetation of the floodplains of the Ipoly river]. - Acta Bot. Acad. Sci. Hung. 13(1-2): 133-168.

KovÁcs, P. and KatonáNÉ-KozÁK, E. (2011): Az Ipoly vízjárásának jellemzése 2010. novemberdecemberében a folyó hazai felsö szakaszán. [Characterization of the water regime of the upper Hungarian section of Ipoly River (interval 2010 November-December]. - Manuscript, Hidrológiai tanulmány. KDV-KÖVIZIG, Budapest, 17 pp.

KURKA, R. (1990): Lindernia dubia: nový zavlečený druh v Československu. - Zpravy Českoslov. Bot. Spol. CSAV 25: 47-48.

LLYod, M. J. (1868): Une plante nouvelle pour la flore de France (Ilysanthes Gratioloides). - Bull. Soc. Bot. France 15: 155-158. http://dx.doi.org/10.1080/00378941.1868.10825212

MARHOLD, K. and HINDÁK, F. (eds) (1998): Checklist of non-vascular and vascular plants of Slovakia. - VEDA, Bratislava, 688 pp.

Medvecká, J., Kliment, J., Májeková, J., Halada, L'., Zaliberová, M., Gojdičová, E., FERÁ KovÁ, V. and JAROLÍMEK, I. (2012): Inventory of the alien flora of Slovakia. - Preslia 84: 257-309.

Molnár, V. A., Pfeiffer, N. and Ristow, M. (2000): Adatok hazai Nanocyperion-fajok ismeretéhez IV. A Lindernia dubia (L.) Pennel [Scrophulariaiceae] Magyarországon. [Data to the knowledge of Nanocyperion-species in Hungary IV. Lindernia dubia (L.) Pennel in Hungary]. - Kitaibelia 5(2): 279-287.

Niklfeld, H. (1971): Bericht über die Kartierung der Flora Mitteleuropas. - Taxon 20(4): 545-571.

Pennell, F. W. (1935): The Scrophulariaceae of eastern temperate North America. - Monogr. Acad. Nat.Sci. Philadelphia, Philadelphia, 650 pp.

Prasad, M. G. and SunojKuma, P. (2014): First record of Lindernia dubia (Linderniaceae) in India and reduction of Lindernia nelliyampathiensis as one of its synonyms. - Phytotaxa 184: 165. http://dx.doi.org/10.11646/phytotaxa.184.3.7

PYšEK, P. and PRACH, K. (1993): Plant invasions and the role of riparian habitats: a comparison of four species alien to central Europe. - J. Biogeogr. 20: 413-420. 
Rahmanzadeh, R., Müller, K., Fischer, E., BARTels, D. and BorsCh, T. (2005): The Linderniaceae and Gratiolaceae are further lineages distinct from the Scrophulariaceae (Lamiales). - Plant Biol. 7: 67-78. http://dx.doi.org/10.1055/s-2004-830444

Richardson, D. M., Pyšek, P., Rejmánek, M., Barbour, M. G., Panetta, D. F. and West, C. J. (2000): Naturalization and invasion of alien plants - concepts and definitions. - Divers. Distrib. 6: 93-107.

RIEZING, N. (2012): Adatok a Győr-Tatai Kisalföld flórájához és vegetációjához. [Data to the flora and vegetation for the Győr-Tata Kisalföld (Hungary)]. - Bot. Közlem. 99(1-2): 81-102.

Soó, R. (1973): A magyar flóra és vegetáció rendszertani-növényföldrajzi kézikönyve V. (Synopsis systematico-geobotanica florae vegetationisque Hungariae V). - Akadémiai Kiadó, Budapest, 723 pp.

Šumberová, K., LososovÁ, Z., DUCHÁČEK, M., HorÁKovÁ, V. and FABŠIČOVÁ, M. (2012): Distribution, habitat ecology, soil seed bank and seed dispersal of threatened Lindernia procumbens and alien Lindernia dubia (Antirrhinaceae) in the Czech Republic. - Phyton 52: 39-72.

Vivian-Smith, G. and STILES, E. W. (1994): Dispersal of salt marsh seeds on the feet and feathers of waterfowl. - Wetlands 14: 316-319. http://dx.doi.org/10.1007/BF03160638

WebB, D. A. and Philcox, D. (1972): Lindernia All. - In: Tutin, T. G. et al. (eds): Flora Europaea. Vol. 3. Cambridge University Press, Cambridge, pp. 203-204.

Yoshino, N., Wang, G.-X., Ito, M., Auld, B., Kohara, H. and Enomoto, T. (2006): Naturalization and dissemination of two subspecies of Lindernia dubia (Scrophulariaceae) in Japan. Weed Biol. Manag. 6: 174-176. http://dx.doi.org/10.1111/j.1445-6664.2006.00213.x.

Yoshino, N., Wang, G.-X., Uchino, A. and Tominaga, T. (2011): Hybridizations and genetic relationships among Lindernia species (Scrophulariaceae): L. procumbens and two subspecies of L. dubia. - Aquat. Bot. 94: 165-171.

Zahradí́ková, K. and OŤahelová, H. (1997): Lindernia. - In: Goliašová, K. (ed.): Flóra Slovenska V/2. VEDA, Bratislava, pp. 72-74.

Zedler, J. B. and Kercher, S. (2004): Causes and consequences of invasive plants in wetlands: opportunities, opportunists and outcomes. - Crit. Rev. Plant Sci. 23: 431-452. http://dx.doi.org/10.1080/07352680490514673.

(submitted: 02.02.2015, accepted: 26.03.2015)

Appendix 1. Detailed description of recent localities of Lindernia dubia in the middle section of the Ipoly valley

Locality-1 (Loc-1):

Hungary; Nógrád county, Nógrádszakál: Ipoly - ca $750 \mathrm{~m} \mathrm{~W}$ from the village. Coordinates: $48.17839^{\circ} \mathrm{N}, 19.51070^{\circ}$ E. $156 \mathrm{~m}$, CEU grid: 7883.1. Date of observation: 14.10.2011.

Description of the habitat: ca 30 senescent individuals with non-matured capsules were found in a fine silty river bed of the Ipoly river in extremely low water conditions. The Nanocyperion community was approx. 2-4 metres broad and linked to marshy (Sparganion) and nitrophilous tall-herb vegetation (Bidention) (Fig. 3). The riverbed is natural, not modified by canalisation. This section of the river is rich in curves, where natural hydrological and biological processes can take place. Associated flowering plants were Cyperus fuscus L., Galium palustre 
L., Potamogeton natans L. f. terrestris Gray, Juncus bufonius L., Butomus umbellatus L., Leersia oryzoides (L.) Sw., Acer negundo L. (seedling), Bidens frondosa L. and Conyza canadensis (L.) Cronquist.

\section{Locality-2 (Loc-2):}

Hungary; Nógrád county, Nógrádszakál: Ráróspuszta - in two subpopulations close to the newly built bridge - ca $200 \mathrm{~m} \mathrm{~N}$ from the main road Nr. 2205. Coordinates: $48.20914^{\circ} \mathrm{N}, 19.54278^{\circ} \mathrm{E}$ and $48.20865^{\circ} \mathrm{N}, 19.53971^{\circ} \mathrm{E}, 164 \mathrm{~m}$, CEU grid: 7883.3. Date of observation: 26.08.2010.

Description of the habitat: one and two vegetative individuals were detected after flooding on the fresh muddy surface of sparse stands of a willow riparian forest (Salicetum albae) on the active floodplain (Fig. 4). The cover of the herb layer was sparse and the species was represented by few individuals that emerged after the flood event. Associated flowering plants were Salix fragilis (in tree layer), Plantago major L., Calystegia sepium (L.) R. Br., Lycopus europaeus L., Myosoton aquaticum (L.) Moench, Poa annua L., Persicaria hydropiper (L.) Delarbre, P. la-

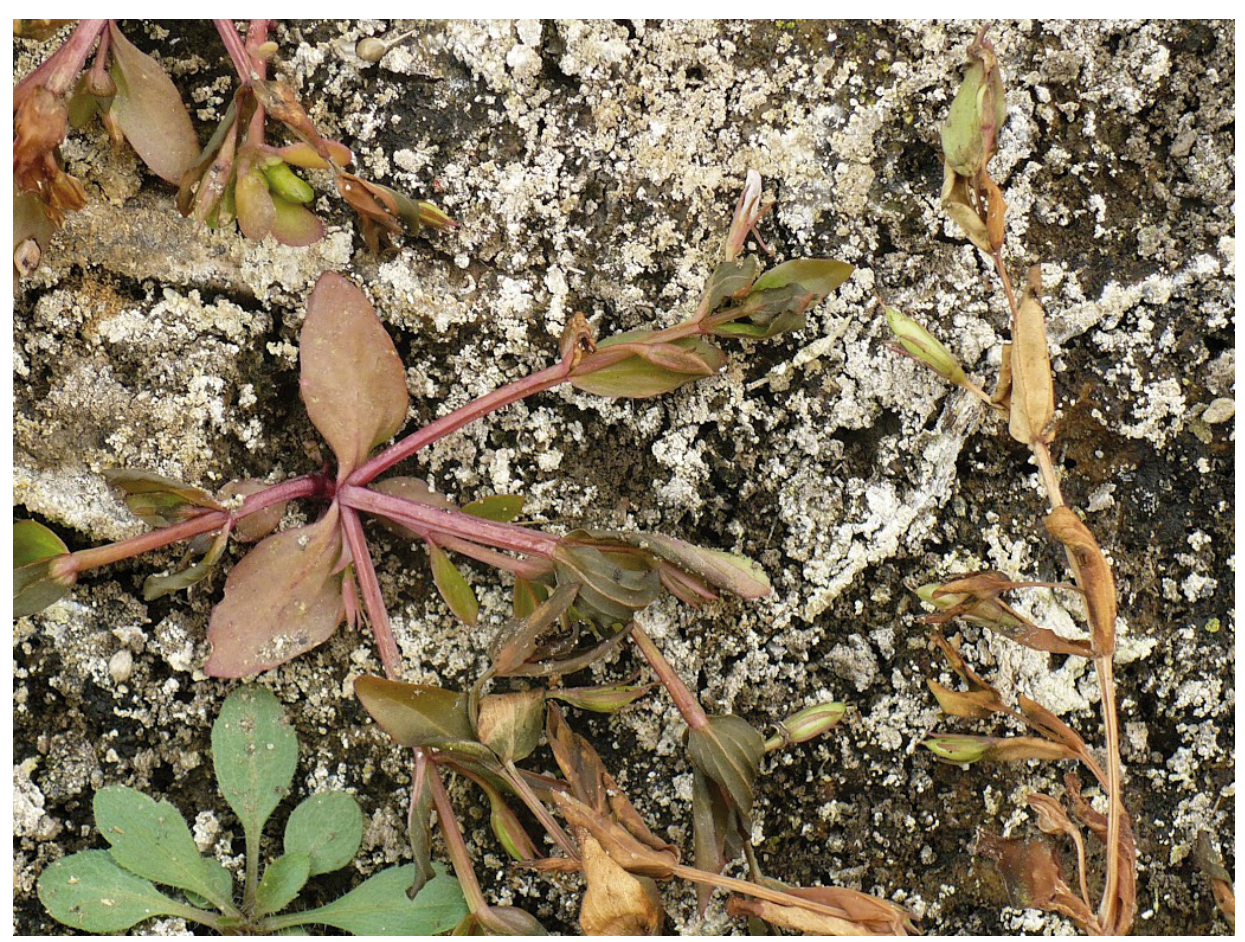

Fig. 3. Lindernia dubia individuals with non-matured capsules in the riverbed of the Ipoly river at Nógrádszakál (Loc-1; 14.10.2011) 

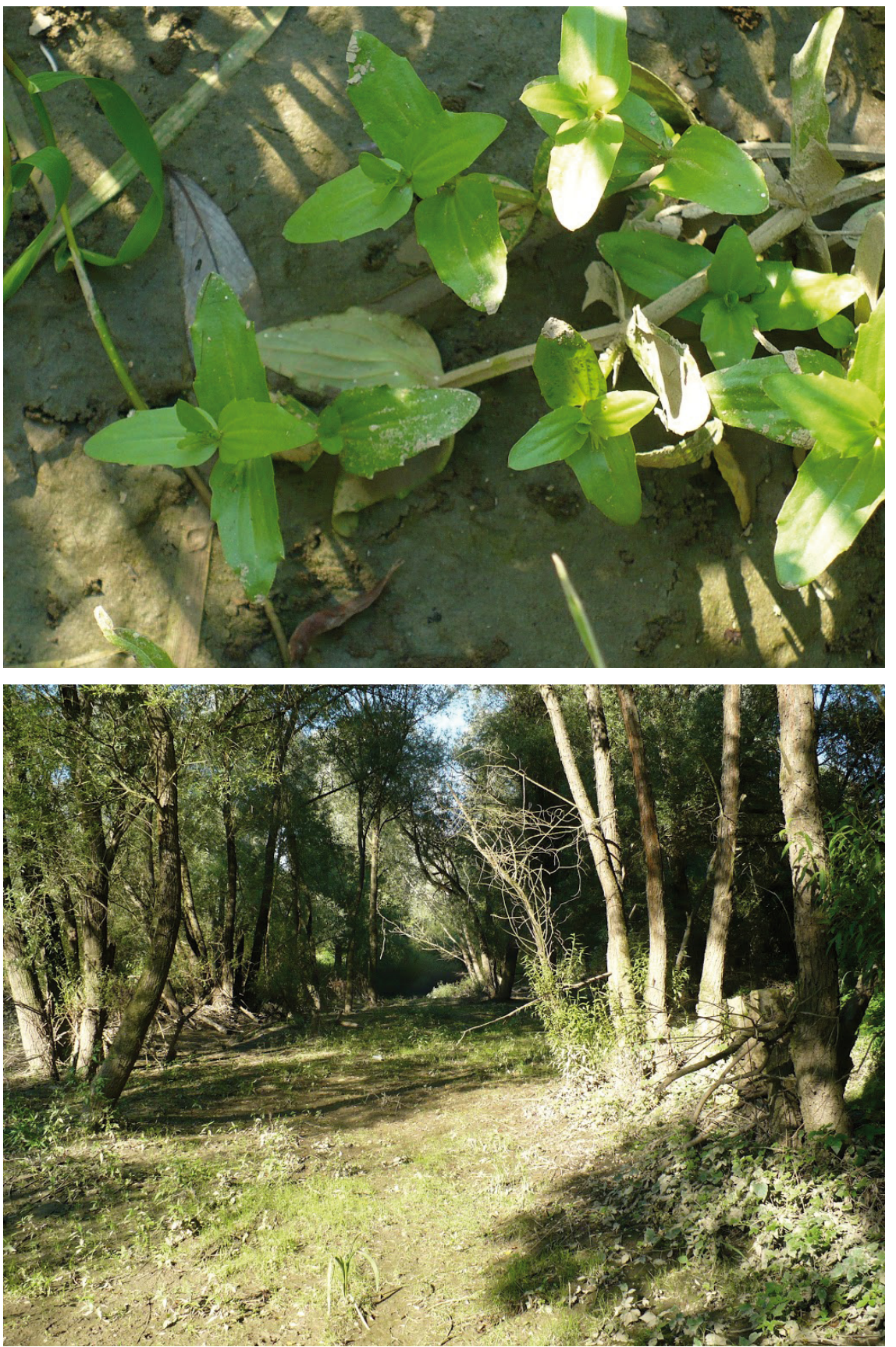

Fig. 4. Lindernia dubia vegetative individual and its habitat (Salicetum albae) at Nógrádszakál, Ráróspuszta (Loc-2; 26.08.2010) 
pathifolia (L.) Delarbre, Rorippa sylvestris (L.) Besser, Ranunculus sceleratus L. and invasive species such as Acer negundo (juv.), Bidens frondosa, and Echinocystis lobata (Michx.) Torr. et A. Gray occurred.

\section{Locality-3 (Loc-3):}

Slovakia; Banskobystrický kraj (county): Trenč: Konopisko - ca $50 \mathrm{~m}$ E from the village. Coordinates: $48.22211^{\circ} \mathrm{N}, 19.58499^{\circ} \mathrm{E} .163 \mathrm{~m}$, CEU grid: 7883.4. Date of observation: 23.10.2010.

Description of the habitat: $c a 15$ vegetative individuals were observed on the muddy surface of a waterlogged arable field forming a temporal pool covered by Nanocyperion community (Fig. 5). Associated flowering plants were Callitriche sp., Peplis portula L., Limosella aquatica L., Potentilla supina L., Lythrum hyssopifolia L., Plantago major L., Symphytum officinale L. and Sparganium emersum Rehmann.

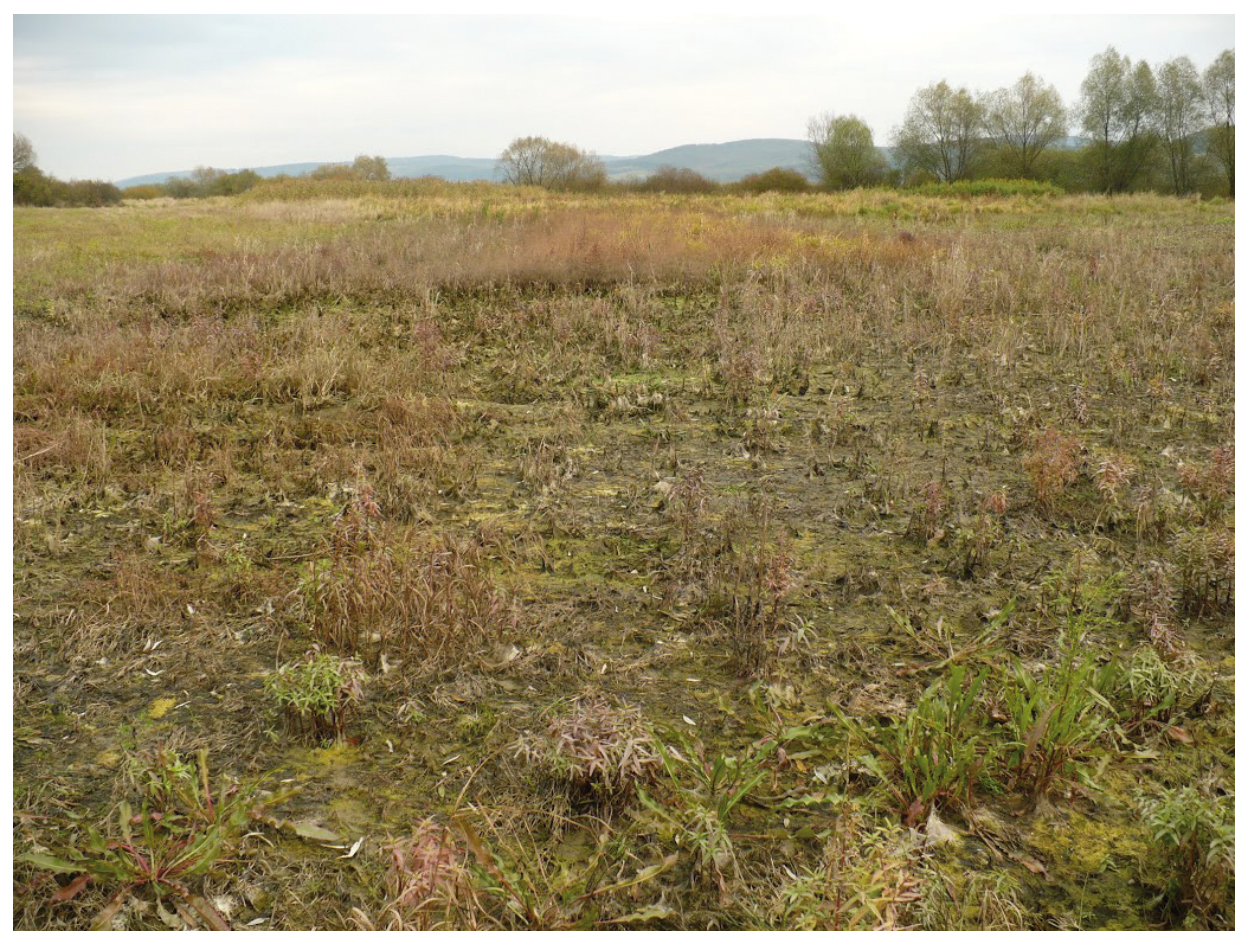

Fig. 5. Habitat of Lindernia dubia at Trenč (Loc-3; 23.10.2010) 